*УДК 336.71

Стрижиченко К.А., д.е.н., професор

Кішинська I.O.

Харківський національний економічний університет імені Семена Кузнеця

\title{
ВИМІРЮВАННЯ ВЕЛИЧИНИ БАНКІВСЬКИХ РИЗИКІВ ЗА НОРМАТИВАМИ РЕГУЛЮВАННЯ ДІЯЛЬНОСТІ БАНКІВ
}

У статті розглянуто теоретичні аспекти управління ризиками кредитного портфеля банку відповідно до нормативів регулювання НБУ.

Ключові слова: банк, кредитний ризик, норматив, регулювання, кредитний портфель, заборгованість.

\section{Stryzhychenko K., Kishynska I.}

\section{MEASURING THE QUANTITY OF BANK RISKS UNDER THE NORMATIVES FOR THE REGULATION OF THE ACTIVITIES OF BANKS}

According to the new requirements of the Basel Committee on Banking Supervision on the Bank's Capital Adequacy, the minimum amount of capital to cover credit risks can be determined using two methods: according to the standardized approach and according to the official data of the National Bank of Ukraine, a method based on internal ratings, the latter has two versions - a stock and progressive approach.

For quantitative assessment of bank risks, statistical and analytical methods, as well as methods of expert assessments are used.

Such a system of risk assessment in banking practices in Ukraine does not provide a clear idea of the numerical parameters of cash losses from banking risks, and therefore is ineffective.

The purpose of the work is to determine the theoretical aspects of risk management of the bank's loan portfolio in accordance with the regulatory norms of the NBU.

As one of the characteristics of the credit risk of banks can be considered the proportion of problem debt in the loan portfolio of banks. There is a need to improve the existing practice of credit risk assessment and management of banking institutions of Ukraine.

The standardized method assumes that the minimum size of the regulatory capital of the bank required to cover credit risk is determined by multiplying the size of the risk position of the bank at the time of default (EAD, Exposure at Default), which is the value of the asset exposed to credit risk by the risk factor and on the solvency ratio. The article presents the algorithm for calculating the risk position of the bank at the time of

* Стрижиченко К.А., Кішинська І.О. 
default (EAD, Exposure at Default).

The complexity of using the standardized method for determining the minimum size of regulatory capital required to cover credit risks in Ukraine is conditioned by the practical absence of nationally recognized rating agencies recognized by the banking supervisory authorities and rather high costs for ordering ratings from foreign rating agencies recognized by the National Bank of Ukraine.

As a promising method for analyzing and assessing credit risk in Ukraine, an approach based on a monetary assessment of credit risk is proposed, according to which it is possible to determine the size of the required reserves to cover the expected credit risks, as well as the amount of necessary economic capital that will cover the bank's credit risks.

Key words: bank, credit risk, normative, regulation, credit portfolio, indebtedness.

Стрыжиченко К.А., Кишинськая. И.А.

\section{ИЗМЕРЕНИЕ ВЕЛИЧИНЫ БАНКОВСКИХ РИСКОВ ПО НОРМАТИВАМ РЕГУЛИРОВАНИЯ ДЕЯТЕЛЬНОСТИ БАНКОВ}

В статье рассмотрены теоретические аспекты управления рисками кредитного портфеля банка в соответствии с нормативами регулирования НБУ.

Ключевые слова: банк, кредитный риск, норматив, регулирование, кредитный портфель, задолженность.

\section{Постановка проблеми в загальному вигляді та її зв'язок 3} важливими науковими і практичними завданнями. Згідно 3 новими вимогами Базельського комітету 3 питань банківського нагляду щодо достатності капіталу банківських установ, мінімальний розмір капіталу для покриття кредитних ризиків можна визначити за допомогою двох методів: за стандартизованим підходом i за офіційними даними Національного банку України методом, що базується на внутрішніх рейтингах, причому останній має дві версії - фондовий та прогресивний підхід.

Для кількісного оцінювання банківських ризиків використовують статистичні й аналітичні методи, а також методи експертних оцінок. Серед недоліків цих методів оцінювання банківських ризиків можна назвати, по-перше, необхідність обробки великих обсягів банківської інформації - для статистичних методів, по-друге, суб'єктивний характер результатів оцінки - для методів експертних оцінок i, по-третє, обмеженість застосування - для аналітичних 
методів оцінювання банківських ризиків.

Загалом, можна стверджувати, що така система оцінювання ризиків у банківській практиці України не дає чіткого уявлення про числові параметри грошових втрат від банківських ризиків, а тому розглядається нами як неефективна і така, що потребує вдосконалення в частині механізму ідентифікації, аналізу й оцінки окремих видів банківських ризиків.

Аналіз останніх досліджень, у яки започатковано вирішення проблеми. Варто зазначити, що в останні роки проблематиці ризику, підходам до його управління та удосконалення методів оцінки приділяється значна увага з боку вітчизняних вчених-теоретиків та фахівців у сфері практичної ризикології. Головні дослідження і публікації, де започатковано розв'язання даної проблеми, належать таким провідним дослідникам як Внукова Н. М., Колодізєв О. М., Рац О. М. та інші.

Цілі статті. Метою роботи є визначення теоретичних аспектів управління ризиками кредитного портфеля банку відповідно до нормативів регулювання НБУ.

Виклад основного матеріалу. В якості однісї з характеристик кредитного ризику банків може розглядатися частка проблемної заборгованості в кредитному портфелі банків. У 2012 року цей показник по банківській системі України сягнув 11,2\%, у 2013 9,6 \%, 2014-8,9 \%, 2015-7,7 \%, а вже у 2016 році - 11,5\%. Це свідчить про начальну потребу вдосконалення існуючої практики оцінки й управління кредитним ризиком банківських установ України й актуальність даної роботи. Стандартизованим методом передбачається, що мінімальний розмір регулятивного капіталу банку (К), необхідного для покриття кредитного ризику, визначається множенням величини ризик-позиції банку у момент дефолту (EAD, Exposure at Default), яка являє собою вартість активу, що наражається на кредитний ризик, на коефіцієнт ризику (КР) та на 8 \% (коефіцієнт платоспроможності):

$$
\mathrm{K}=\mathrm{EAD} \times \mathrm{KP} \times 8 \%
$$

При цьому розрахунок EAD здійснюється за алгоритмом, представленим у табл. 1 [1]. 
Економічні науки". - Серія "Облік і фінанси". - Випуск 15 (57). - 2018.

Таблиця 1

Розрахунок ризик-позиції банку у момент дефолту

(EAD, Exposure at Default)

\begin{tabular}{|c|c|}
\hline $\begin{array}{l}\text { Вимога, що підпадає } \\
\text { під кредитний ризик }\end{array}$ & Ризик-позиція у момент дефолту \\
\hline Активи & $\begin{array}{c}\text { Номінальна вартість вимоги - (Спеціальні } \\
\text { резерви на покриття сумнівних вимог + } \\
\text { Загальні резерви під невизначені ризики) }\end{array}$ \\
\hline $\begin{array}{c}\text { Традиційні позабалан- } \\
\text { сові операції }\end{array}$ & $\begin{array}{c}\text { Вартість вимоги х Кредитний конверсійний } \\
\text { коефіцієнт (ССF: 0\%, 20\%, 50\%, 100\%)- } \\
\text { Пом'якшення кредитних ризиків (неттінг) }\end{array}$ \\
\hline $\begin{array}{l}\text { Новітні позабалансові } \\
\text { операції (строкові опе- } \\
\text { рації, ф’ючерси, опціо- } \\
\text { ни і свопи) }\end{array}$ & $\begin{array}{l}\text { Метод ринкової оцінки: (Теперішня + Май- } \\
\text { бутня вартість ризиків) - Пом’якшення кре- } \\
\text { дитних ризиків (неттінг) Строковий метод: } \\
\text { Вартість вимоги × Визначена строкова став- } \\
\text { ка }\end{array}$ \\
\hline Всі активи & $\begin{array}{l}\text { - Пом'якшення кредитних ризиків: } \\
\text { 1) Неттінг (взаємна компенсація вимог та } \\
\text { зобов'язань за збалансованими операціями): } \\
\text { ЕAD зменшується на сальдо взаємних ви- } \\
\text { мог; 2) Фінансові забезпечення за комплекс- } \\
\text { ним підходом: ЕAD зменшується на скоре- } \\
\text { говану вартість фінансової гарантії }\end{array}$ \\
\hline
\end{tabular}

Коефіцієнт ризику (КР) же визначається залежно від категоpiï вимоги, категорії боржника та зовнішнього рейтингу (табл. 2) $[4]$.

Таблиця 2

Визначення коефіцієнту ризику (КР) залежно від категорії вимоги, категорії боржника та зовнішнього рейтингу

\begin{tabular}{|c|c|c|c|c|c|c|c|}
\hline $\begin{array}{c}\text { Категорії довгостро- } \\
\text { кових рейтингів (від - } \\
\text { до) }\end{array}$ & $\frac{1}{<}$ & $\begin{array}{l}\dot{4} \\
+ \\
\end{array}$ & 离离 & $\begin{array}{l}\stackrel{m}{m} \\
+ \\
\stackrel{m}{m}\end{array}$ & $\begin{array}{l}\infty \\
+\infty\end{array}$ & 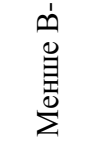 & 蛋 \\
\hline 1 & 2 & 3 & 4 & 5 & & 6 & 7 \\
\hline $\begin{array}{l}\text { 1) Центрально- } \\
\text { державні установи }\end{array}$ & $0 \%$ & $20 \%$ & $\begin{array}{l}50 \\
\%\end{array}$ & 100 & & $150 \%$ & $100 \%$ \\
\hline
\end{tabular}


Продовження табл. 2

\begin{tabular}{|c|c|c|c|c|c|}
\hline 1 & 2 & 3 & 4 & 6 & 7 \\
\hline 2) Банки: Варіант I & $20 \%$ & $50 \%$ & $100 \%$ & $150 \%$ & $100 \%$ \\
\hline 2) Банки: Варіант I & $20 \%$ & $50 \%$ & $100 \%$ & $150 \%$ & $50 \%$ \\
\hline ПСП менше 3м & \multicolumn{2}{|c|}{$20 \%$} & $50 \%$ & \multirow{2}{*}{$\begin{array}{l}150 \% \\
150 \% \\
\end{array}$} & $20 \%$ \\
\hline 3) Корпорації & $20 \%$ & $50 \%$ & $100 \%$ & & $100 \%$ \\
\hline $\begin{array}{l}\text { Категорії коротко- } \\
\text { строкових рейтингів }\end{array}$ & \multicolumn{2}{|c|}{$\mathrm{A} 1 / \mathrm{P} 1$} & $\mathrm{~A} 2 / \mathrm{P} 2$ & $\mathrm{~A} 3 / \mathrm{P} 3$ & Решта \\
\hline Всі боржники & \multicolumn{2}{|c|}{$20 \%$} & $50 \%$ & $100 \%$ & $150 \%$ \\
\hline \multicolumn{6}{|c|}{ Залежно від відношення до певного класу активів, але незалежно від рейтингу } \\
\hline \multicolumn{5}{|c|}{ Вид активу } & KP \\
\hline \multicolumn{5}{|c|}{ 4) Роздрібний регулятивний портфель } & $75 \%$ \\
\hline \multicolumn{5}{|c|}{ 5) Іпотечні кредити: а) житлова нерухомість } & $35 \%$ \\
\hline \multicolumn{5}{|c|}{ б) комерційна нерухомість } & $100 \%$ \\
\hline \multicolumn{5}{|c|}{ 6) Капіталовкладення: а) в небанківські установи } & $150 \%$ \\
\hline \multicolumn{5}{|c|}{ б) в банківські установи } & $100 \%$ \\
\hline \multicolumn{5}{|c|}{ 7) Вимоги, прострочені більше, ніж на 90 днів } & $0-150 \%$ \\
\hline \multicolumn{5}{|c|}{ 8) Інші активи, що не належать до торгового портфелю } & $100 \%$ \\
\hline \multicolumn{4}{|c|}{$\begin{array}{l}\text { - Пом’якшення кредитних ризиків: } \\
\text { а) Фінансові забезпечення за простим підходом } \\
\text { б) Гарантії та кредитні деривативи }\end{array}$} & & $\begin{array}{l}\text { Р гаран- } \\
\text { та }\end{array}$ \\
\hline
\end{tabular}

Як видно з табл. 2 складність застосування стандартизованого методу визначення мінімального розміру регулятивного капіталу банку, необхідного для покриття кредитних ризиків, в Україні зумовлюється практичною відсутністю визнаних органами банківського нагляду вітчизняних рейтингових агентств і достатньо високими затратами на замовлення рейтингу від зарубіжних рейтингових агентств, що визнані Національним банком України.

Висновки. Як перспективну методику аналізу й оцінки кредитного ризику в Україні пропонуємо підхід, що базується на грошовій оцінці кредитного ризику, відповідно до якого можна визначати розміри необхідних резервів для покриття очікуваних кредитних ризиків, а також величину необхідного економічного капіталу, що покриватиме зазнані банком кредитні ризики. Даний підхід вимагає від Національного банку України таких дій. По-перше, розробити шкалу критеріїв (опираючись на передовий світовий досвід), за якими буде визначатися ймовірність дефолту вимоги банку, що містить кредитний ризик. По-друге, розробити відповідну нормативно-законодавчу базу щодо запровадження в українську 
банківську практику методу грошової оцінки кредитного ризику, що буде включатися до мінімального розміру капіталу банку. I, потретє, розробити механізм контролю за правильністю визначення банками власного кредитного ризику за даною методикою й адекватністю формування ними резервів під ці ризики з метою захисту інтересів вкладників та кредиторів банку.

1. Вергелюк Ю. Ю. Методи та інструменти управління кредитним ризиком при обслуговуванні корпоративних клієнтів банку / Ю. Ю. Вергелюк // Вісник Університету банківської справи Національного банку України. - 2013. - № 1. - С. 195-198.

2. Внукова Н. М. Іерархія факторів ризиків банку при овердрафтному кредитуванні / Н. М. Внукова, О. В. Мовчан // Науковий вісник Ужгородського університету. Сер : Економіка. - 2013. - № 4. - С. 6-10.

3. Колодізєв О. М. Оптимізація кредитного портфеля банку за критеріями прибутковості, ризику та ліквідності / О. М. Колодізєв, В. С. Буряк // Фінансовокредитна діяльність: проблеми теорії та практики. - 2015. - № 1. - С. 19-27.

4. Офіційний сайт Національного банку України [Електронний ресурс] / Національний Банк України - Режим доступу : https://www.bank.gov.ua/control /uk/index.

5. Рац О. М. Дослідження впливу якості кредитного портфелю на ефективність кредитної діяльності банку як складова моніторингу кредитного ризику / О.М.Рац // Технологический аудит и резервы производства. 2015. - № 1(5). C. 41-45.

*УДК: 657

Ткачук I.M., к.е.н., доцент

Луцький національний технічний університет

\section{ІНВЕНТАРИЗАЦІЯ ЯК НЕВІД'ЄМНИЙ ІНСТРУМЕНТ КОНТРОЛЮ}

У статті представлено дослідження теоретичних та практичних основ проведення інвентаризації, як невід'ємного інструменту контролю. Адже, саме інвентаризація дає можливість проконтролювати виконання правил і умов зберігання i використання майна підприємства.

Ключові слова: інвентаризація, контроль, облік, звітність, активи, зобов'язання.

* Ткачук I.M. 